\title{
New species of Pseudosinella Schäffer, 1897 (Collembola, Entomobryidae) from Spain
}

\author{
RAFAEL JORDANA ${ }^{1,3} \&$ ENRIQUE BAQUERO ${ }^{2}$ \\ ${ }^{\prime}$ Department of Zoology and Ecology, University of Navarra, P.O. Box 177, E-31080 Pamplona, Navarra, Spain. \\ E-mail: ${ }^{1}$ rjordana@unav.es; ${ }^{2}$ ebaquero@unav.es \\ ${ }^{3}$ Corresponding author
}

\begin{abstract}
The revision of the specimens of Pseudosinella at the Bonet Collection (MNCN, Museo Nacional de Ciencias Naturales-CSIC, Madrid) have allow us to describe four new species found among 175 slides with more than 420 specimens. One of them belongs to the petterseni-group (unguiculus with a fully developed tooth and without eyes). The differential characters of Pseudosinella species from Christiansen (2007), and four characters more, have been used for comparison with the related species.
\end{abstract}

Key words: Collembola, Pseudosinella, Bonet collection, description, new species

\section{Introduction}

Pseudosinella is a very well studied genus. Chaetotaxy and morphological characters are used for the species identification, which facilitate the description of new species when new material is obtained from field. Christiansen et al. (1983) made a revision of the species studying the specimens cited from Europe and other countries, and set up the code of species macrochaetotaxy. Christiansen et al. (1990) designed a computer assisted identification of the species of Pseudosinella adding some more characters. This electronic key is now in the Web (Christiansen, 2007), and it is in permanent actualization. The revision of the specimens of Pseudosinella from the Bonet Collection (MNCN, Museo Nacional de Ciencias Naturales-CSIC, Madrid) allowed us to find misidentified specimens, some belonging to species not described. Among the collection a slide with two specimens identified as P. petterseni was found. Börner in 1901 described P. petterseni Börner, 1901 from Freuenberg (near Marburg), Germany. Bonet in 1931 cited and described this species from Spain as conspecific with Börner's species. A comparison of this species with the rest of similar species of the petterseni-group shows that it is a new species. Three additional new species have been easily detected using the combination of the chaetotaxy formula and the other characters used for the species description.

\section{Material and methods}

The species described in this paper came from to the Collembola collection keeping in the Museo Nacional de Ciencias Naturales-CSIC, Madrid (Spain), some of them from the Bonet collection. The observations of the slides have been done under a microscope Olympus BX51-TF with a multi-viewing system and phase contrast, and an Olympus BX50-F4 with differential interference contrast (DIC). For the measurements a U-DA 
drawing attachment UIS (Universal Infinity System) and a scale calibrated with a slide of Graticules Ltd. (1 $\mathrm{mm}$ divided in 100 parts) has been used. The related literature has been reviewed in order to make a comparative table to deal with the new species of the petterseni-group.

\section{Species descriptions}

\section{Pseudosinella pseudopetterseni sp. nov.}

Figs 1-6, Tables 1 and 2

Type material. Mieza, Salamanca (Spain). Holotype: female, slide 509N Bonet Collection (MNCN115coll2003(3)55), C. Bolivar Legit, 7.i.1931. Paratypes: 1 specimen in the same slide as the holotype, in the Museo Nacional de Ciencias Naturales-CSIC, Madrid (Spain).

Description. Maximum length $1.55 \mathrm{~mm}$ (same length in the two specimens). Without pigment (possibly faded along time and we do not know its pattern). Without eyes. Ratio antenna/cephalic diagonal 1.57 and 1.72 respectively. Antennal segments I/II/III/IV ratios 1/3.75/3.5-3.75/6.5-7.5. Sensorial setae $\mathbf{s}$ of the sensory organ of antennal segment III short, slightly curved and rod like. Apical region of the antennal segments II and III with a pseudopore in an internal-ventral position, far from the setae line. Apical vesicle absent from antennal segment IV.

Formula of the labial base (Fig. 3): $\mathbf{M}_{1} \mathbf{M}_{2} \mathbf{R E} \mathbf{L}_{1} \mathbf{L}_{2}$, all setae ciliated, $\mathbf{R}$ as a ciliated mesochaeta, more than $1 / 2$ in length of the neighbor ciliate macrochaetae $\mathbf{M}_{2}$.

Formula of the dorsal macrochaetae: R001/00/0201+2. Abdominal tergite II chaetotaxy: $\mathbf{p a B} \mathbf{B}_{\mathbf{1}} \mathbf{q}_{\mathbf{2}}$ (Fig. 1), seta $\mathbf{a}$ as broad ciliated microchaeta. $\mathbf{R}$ complex with only $\mathbf{R}_{\mathbf{0}}$ and $\mathbf{R}_{\mathbf{1}}$ (Fig. 2). Accessory seta $\mathbf{s}$ in the anterior trichobothrial complex of abdominal tergite IV present (Fig. 4). P seta on abdominal tergite IV anterior to the trichobothrium, as a ciliated mesochaeta (Fig. 4), similar to P. gamae Gisin, 1967. Medial seta $\mathbf{M}_{1}$ at the level of the trichobothrium $\mathbf{T}_{1}$. Pseudopore near $\mathbf{M}_{1}$ in the holotype, and at the same distance to $\mathbf{M}_{1}$ and $\mathbf{M}_{2}$ in the paratype.

Unguis (Fig. 5) with dental plate occupying 50\% of the basal internal edge; basal teeth of different size, medial tooth well developed, approximately $75 \%$ from base of total unguis. Unguiculus appendage acuminate with a fully developed external tooth. Dorsal tibiotarsal tenent hair clavate. Legs without scales. Retinaculum with $4+4$ teeth and one ciliated seta. One internal and two external setae related to two distal pseudopores of manubrial plate. Mucro with distal tooth longer than the anteapical; the basal spine reaches to the tip of the distal tooth (Fig. 6).

The characters defined by Christiansen, Bellinger \& Gama (1990) for Pseudosinella and the 40 characters used by Christiansen (2007) in his Delta key have been used for identification, but have been added four new characteristics (Table 2).

Etymology. The species name is referred to the confusion with P. petterseni.

Discussion. According to the dorsal macrochaetotaxy $(\mathbf{R 0 0 1 / 0 0 / 0 2 0 1 + 2})$, and the presence of seta $\mathbf{s}$ in the anterior trichobothrial complex of the abdominal tergite IV, this species belongs to the group formed by $P$. voylesi Christiansen, 1982 and P. leoni Christiansen, 1982 (Table 1). Both species are separated by the chaetotaxy of the labium and abdominal tergite II. P. petterseni has been included in this table because the similarity with P. pseudopetterseni sp. nov., that was misidentified as P. petterseni by Bonet (1931).

Remarks.The species with a fully developed external tooth on the unguiculus and without eyes ( $P$. petterseni species group for many authors) are P. petterseni (Germany), P. violenta (Folsom, 1924) (USA), $P$. rolfsi Mills, 1932 (USA), P. halofila Bagnall, 1939 (England), P. espana Christiansen, 1960 (USA), P. anderseni Gisin, 1967 (Switzerland), P. gamae (Portugal), P. biunguiculata Ellis, 1967 (Central America), P. hrabei Rusek, 1979 (Czech Republic), P. certa Christiansen \& Bellinger, 1980 (USA), P. sera Christiansen \& Bell- 
inger, 1980 (USA), P. ashmoleorum Gama, 1988 (Açores), P. bachae Luciáñez \& Simón, 1994 (Spain), $P$. gajui Luciáñez \& Simón, 1994 (Spain), P. espanita Christiansen \& Bellinger, 1996 (USA), P. bellingeri Wang, Christiansen \& Chen, 2002 (Tibet), P. caoi Chen, Wang \& Christiansen, 2002 (China) and P. soriensis Simón \& Signoret, 2006 (Spain).

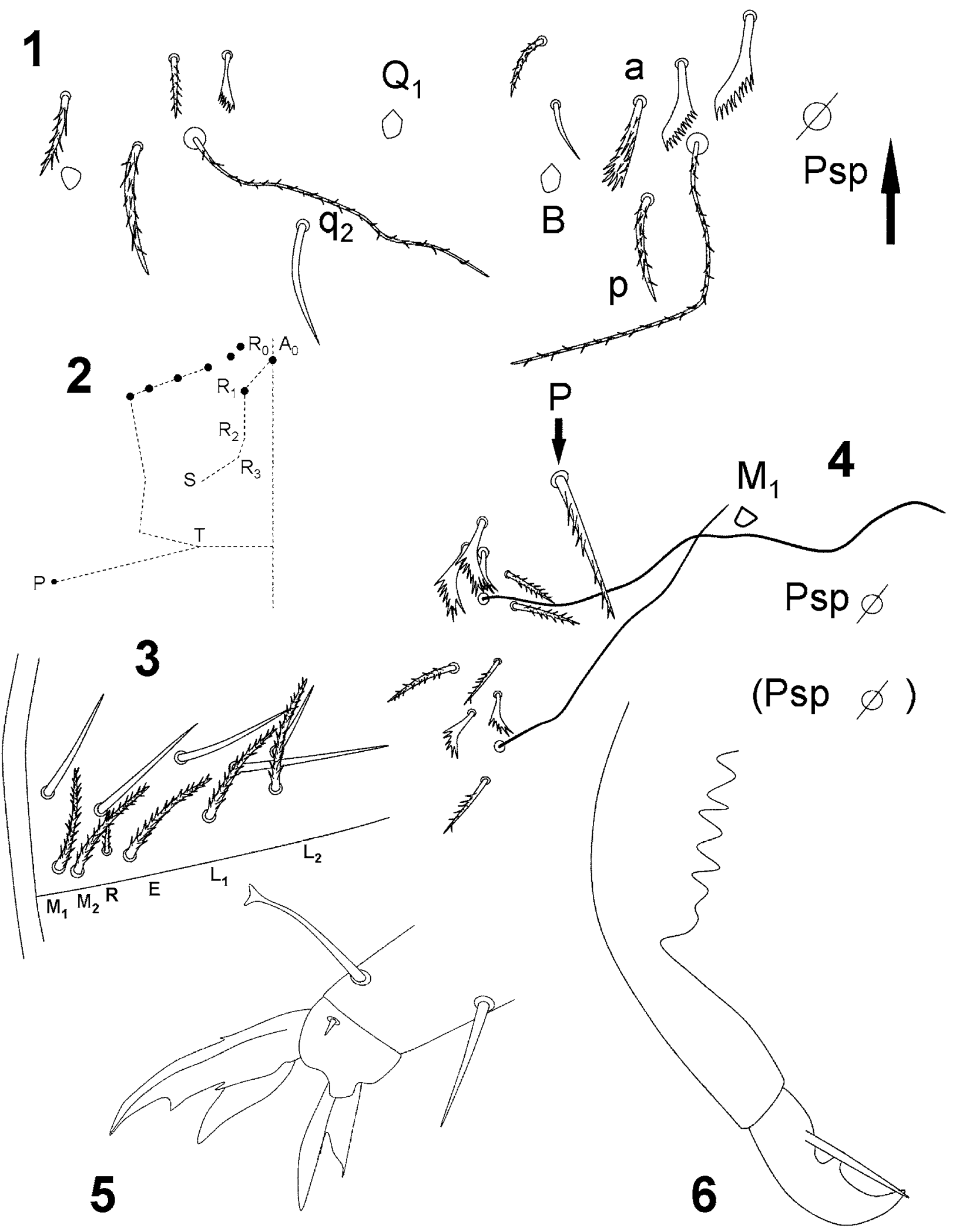

FIGURES 1-6. Pseudosinella pseudopetterseni sp. nov.: 1, chaetotaxy of abdominal segment II; 2, head macrochaetotaxy; 3, labium chaetotaxy; 4, trichobothrial complex of abdominal segment IV; 5, distal part of leg III; 6, mucro. 
TABLE 1. Comparison of $P$. pseudopetterseni sp. nov. with $P$. petterseni and the species with the same dorsal macrochaetotaxy. Abbreviations. Tenent hair: I, pointed; Y, clavate. Distribution: A, North America; H, Holartic; E, Europe; C, caves; S, surface. Labium chaetotaxy: in capitals, seta ciliated; lower-case, seta smooth; -, absence of seta. Differences in bold.

\begin{tabular}{llllllll}
\hline Species & Author & Eyes & Tenent hair & Distribution & Chaetotaxy & Abd. segment II & Labium \\
\hline $\begin{array}{l}P . \text { pseudopetterseni } \\
\text { sp. nov. }\end{array}$ & & 0 & $\mathrm{Y}$ & $\mathrm{E}, \mathrm{S}$ & $\mathrm{R} 001 / 00 / 0201+2 / \mathrm{s}$ & paBQq & MMRELL \\
$\begin{array}{l}\text { P. voylesi } \\
\text { Christiansen, }\end{array}$ & $1-2$ & $\mathrm{I}$ & $\mathrm{H}, \mathrm{C}$ & $\mathrm{R} 001 / 00 / 0201+2 / \mathrm{s}$ & -ABqq & mmrell \\
$\begin{array}{l}\text { P. leoni } \\
1982\end{array}$ & $\begin{array}{l}\text { Christiansen, } \\
1982\end{array}$ & 0 & $\mathrm{Y}$ & $\mathrm{H}, \mathrm{C}$ & $\mathrm{R} 001 / 00 / 0201+2 / \mathrm{s}$ & -ABqq & mmrell \\
$\begin{array}{l}\text { P. petterseni } \\
\text { Börner, 1901 }\end{array}$ & 0 & $\mathrm{Y}$ & $\mathrm{E}, \mathrm{A}, \mathrm{S}$ & $\mathrm{R} 011 / 22 / 0201+2 / \mathrm{s}$ & pABqq & MMrELL \\
\hline
\end{tabular}

TABLE 2. Comparison of the species belonging to the petterseni-group.

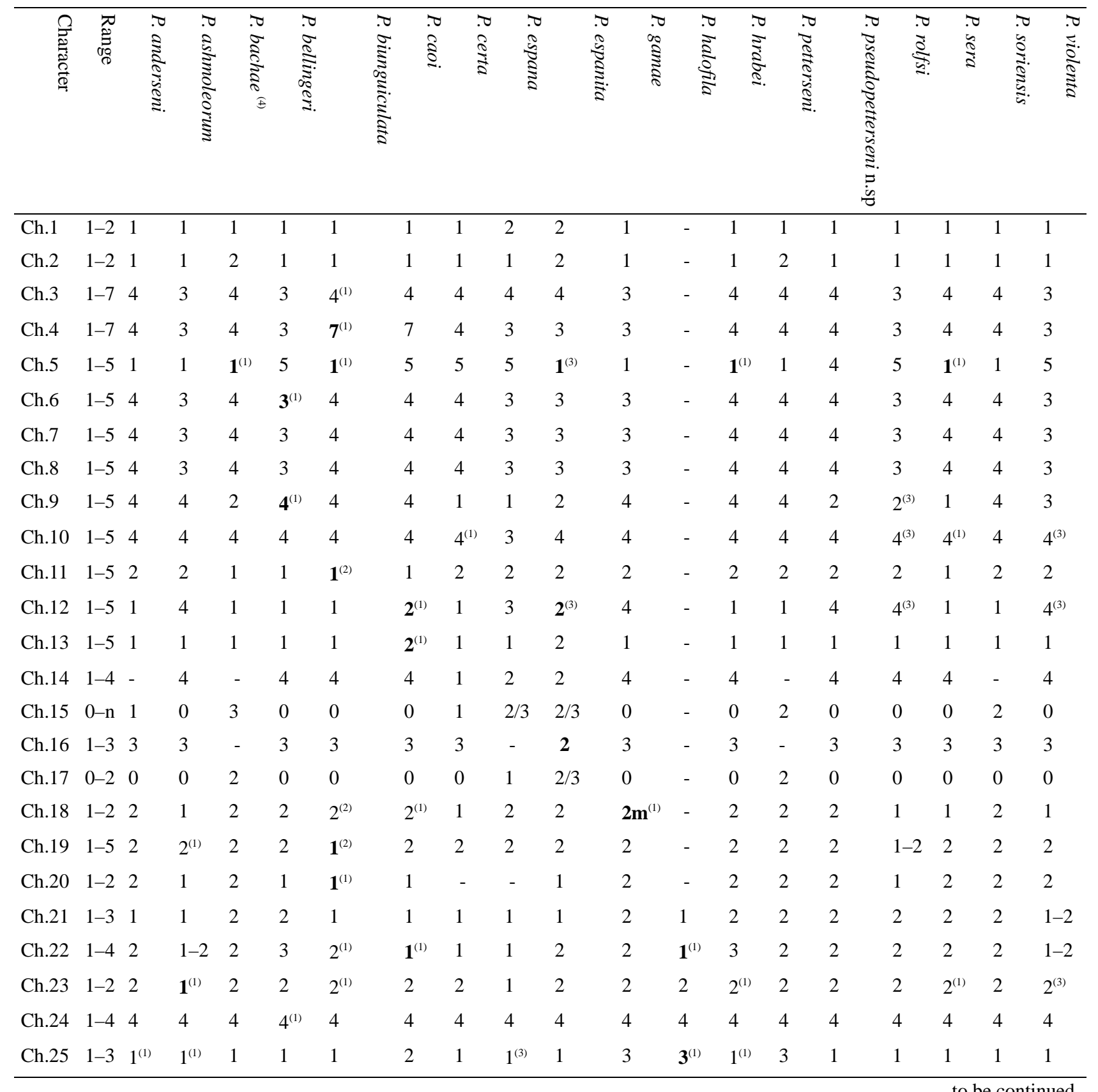


TABLE 2 (continued).

\begin{tabular}{|c|c|c|c|c|c|c|c|c|c|c|c|c|c|c|c|c|c|c|c|}
\hline 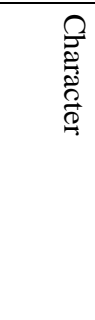 & $\begin{array}{l}\nabla 0 \\
\tilde{O} \\
0 \\
0 \\
0\end{array}$ & 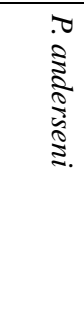 & 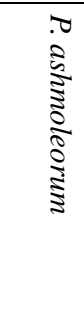 & 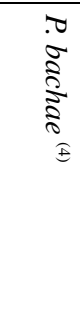 & $\begin{array}{c}\text { D. } \\
0 \\
0 \\
0 \\
0 \\
0 \\
0\end{array}$ & 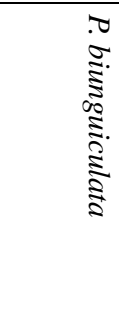 & $\begin{array}{l}7 \\
\delta \\
\delta\end{array}$ & $\begin{array}{l}7 \\
3 \\
3 \\
2\end{array}$ & $\begin{array}{l}7 \\
0 \\
5 \\
5 \\
5 \\
5\end{array}$ & & $\begin{array}{c}7 \\
\infty \\
\infty \\
\$ \\
\vdots \\
\vdots\end{array}$ & 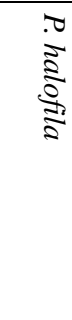 & 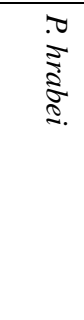 & 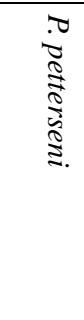 & 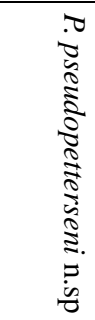 & 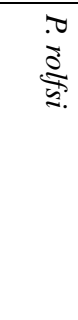 & $\begin{array}{l}\vec{v} \\
\vec{a} \\
\overrightarrow{2}\end{array}$ & 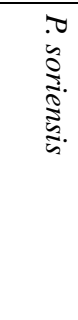 & 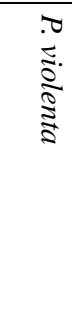 \\
\hline Ch.26 & $\mathrm{n}$ & 0 & 0 & 0 & 0 & 0 & 0 & 0 & 0 & 0 & 0 & 0 & 0 & 0 & 0 & 0 & 0 & 0 & 0 \\
\hline Ch.27 & $1-5$ & 2 & - & 2 & 2 & $\mathbf{2}^{(1)}$ & 2 & - & 1 & $2-3$ & 1 & - & - & - & 1 & 2 & 2 & 1 & 1 \\
\hline Ch.28 & $0-\mathrm{n}$ & 2 & - & 2 & $\begin{array}{l}\text { 1- } \\
3^{(1)}\end{array}$ & $1^{(1)}$ & 1 & - & $6-7$ & 2 & 1 & - & - & - & 2 & $7-8$ & $4-5$ & 2 & $1-3$ \\
\hline Ch.29 & $1-3$ & 2 & 1 & 2 & 2 & 2 & 3 & 1 & 1 & 1 & 2 & $4^{(1)}$ & 2 & 2 & 2 & 2 & 2 & 2 & 3 \\
\hline Ch.30 & $1-9$ & 1 & 1 & 1 & 6 & 3 & 6 & 2 & 2 & 2 & 1 & 1 & 1 & 1,6 & 1 & 2 & 2 & 1 & 2 \\
\hline Ch.31 & $1-3$ & - & - & $1^{(1)}$ & $1^{(1)}$ & 1 & 1 & 1 & 1 & 1 & - & - & 1 & - & 1 & 1 & 1 & 1 & 1 \\
\hline Ch.32 & $1-3$ & 1 & 1 & 1 & -(1) $^{(1)}$ & $1^{(1)}$ & 1 & 1 & 3 & $2-3$ & 1 & - & 1 & - & 1 & 1 & 1 & 1 & 2 \\
\hline Ch.33 & $\mathrm{n}$ & 1.3 & 2.2 & 1.03 & 1.5 & 0.9 & 1.1 & 1.2 & 1.1 & 1.8 & 1.6 & 1.5 & 1.5 & - & 1.55 & 2.0 & 1.2 & 0.7 & 2.1 \\
\hline Ch.34 & $\%$ & $66 \%$ & - & $68 \%$ & $\begin{array}{l}73- \\
84 \%\end{array}$ & $50 \%$ & $-^{(1)}$ & - & - & $\begin{array}{l}20- \\
26 \%\end{array}$ & $60 \%$ & - & $70 \%$ & $\begin{array}{l}60- \\
72 \%\end{array}$ & $65 \%$ & $55 \%$ & $53 \%$ & $70 \%$ & $\begin{array}{l}63- \\
78 \%\end{array}$ \\
\hline Ch.35 & $\mathrm{n}$ & 1.5 & $\begin{array}{l}1.8- \\
2.1\end{array}$ & 1.55 & $\begin{array}{l}0.7- \\
1.44\end{array}$ & $\begin{array}{l}1.4-1.6 \\
(1,2)\end{array}$ & $\begin{array}{l}1.2- \\
1.38\end{array}$ & 1.6 & 1.3 & $\begin{array}{l}1.3- \\
1.7\end{array}$ & 1.6 & 2 & 1.9 & $\begin{array}{l}1.33 \\
(1)\end{array}$ & $\begin{array}{l}1.57- \\
1.73\end{array}$ & 1.3 & 1.1 & 1.68 & $\begin{array}{l}1.2- \\
2.1\end{array}$ \\
\hline Ch.36 & $1-3$ & - & - & $1^{(1)}$ & 2 & 3 & 3 & - & 3 & 3 & - & - & - & - & 1 & 1 & 3 & - & 1 \\
\hline Ch.37 & $1-2$ & 2 & 2 & $2^{(1)}$ & 2 & 2 & 2 & 2 & 2 & 2 & 2 & - & 2 & 2 & 2 & 2 & 2 & 2 & 2 \\
\hline Ch.38 & $1-2$ & 2 & 1 & 2 & 1 & 2 & 2 & 2 & 2 & 2 & 1 & - & 2 & 2 & 2 & 1 & 2 & 2 & 1 \\
\hline Ch.39 & $1-2$ & 2 & 1 & 2 & 1 & $1-2$ & 2 & 2 & 2 & 2 & 1 & - & 2 & 2 & 1 & 1 & 2 & 2 & 1 \\
\hline Ch.40 & $1-2$ & 1 & 1 & 1 & 1 & 1 & 1 & 1 & 1 & 1 & 1 & - & 1 & 1 & 1 & 1 & 1 & 1 & 1 \\
\hline Ch.41 & $1-2$ & 2 & 2 & 2 & 1 & 2 & 2 & - & 1 & 2 & 2 & - & 2 & 2 & 2 & 2 & - & 2 & 2 \\
\hline Ch.42 & $1-2$ & - & - & - & 1 & - & - & - & - & 1 & - & - & - & - & 1 & - & - & 1 & - \\
\hline Ch.43 & $1-2$ & - & - & - & - & 1 & - & - & - & 1 & - & - & - & - & - & - & - & 1 & - \\
\hline Ch.44 & $1-2$ & - & 2 & 2 & 1 & 1 & 2 & $2+$ & $2+$ & 2 & - & - & - & - & $2+$ & 1 & 1 & - & 2 \\
\hline
\end{tabular}

Character, place, description.

Ch.1, dorsal cephalic macrochaeta S, 1. absent/ 2. present;

Ch.2, dorsal cephalic macrochaeta T, 1. absent/ 2. Present;

Ch.3, m1 <ventral labial>, 1. smooth microchaeta/ 2. ciliated microchaeta/ 3. smooth macrochaeta/ 4. ciliated macrochaeta/ 5. smooth macrochaeta with supplementary seta/ 6. ciliated macrochaeta with supplementary seta/ 7. Absent;

Ch.4, m2 <ventral labial>, 1. smooth microchaeta/ 2. ciliated microchaeta/ 3. smooth macrochaeta/ 4. ciliated macrochaeta/ 5. smooth macrochaeta with supplementary seta/ 6. ciliated macrochaeta with supplementary seta / 7. absent;

Ch.5, $\mathrm{r}<$ ventral labial>, 1. smooth microchaeta/ 2. ciliated microchaeta/ 3. smooth macrochaeta/ 4. ciliated macrochaeta/ 5. absent;

Ch.6, e <ventral labial>, 1. smooth microchaeta/ 2. ciliated microchaeta/ 3. smooth macrochaeta/ 4. ciliated macrochaeta/ 5. absent;

Ch.7, L1 <ventral labial, 1. smooth microchaeta/ 2. ciliated microchaeta/ 3. smooth macrochaeta/ 4. ciliated macrochaeta/ 5. absent;

Ch.8, L2 <ventral labial>, 1. smooth microchaeta/ 2. ciliated microchaeta/ 3. smooth macrochaeta/ 4. ciliated macrochaeta/ 5. absent;

Ch.9, a <second abdominal seta>, 1. smooth microchaeta/ 2. ciliated microchaeta/ 3. smooth macrochaeta/ 4. ciliated macrochaeta/ 5. absent;

Ch.10, b <second abdominal seta>, 1. smooth microchaeta/ 2. ciliated microchaeta/ 3. smooth macrochaeta/ 4. ciliated macrochaeta/ 5. absent;

Ch.11, p <second abdominal seta>, 1. absent/ 2. present;

Ch.12, q1 <second abdominal seta>, 1. smooth microchaeta/ 2. ciliated microchaeta/ 3. smooth macrochaeta/ 4. ciliated macrochaeta/ 5. absent; 
Ch.13, q2 <second abdominal seta>, 1. smooth microchaeta/ 2. ciliated microchaeta/ 3. smooth macrochaeta/ 4. ciliated macrochaeta/ 5. absent;

Ch.14, posterior thoracic segment 2 macrochaeta, 1. acuminate/2. clavate/ 3. truncate/ 4. absent;

Ch.15, posterior thoracic segment 2 macrochaeta, number;

Ch.16, thoracic segment 3 macrochaetae, 1.acuminate/ 2. clavate/ 3. absent,

Ch.17, thoracic segment 3 macrochaetae, number;

Ch.18, anterior lateral (P) fourth abdominal dorsal macrochaetae, 1. 0/ 2. 1/ 2m. 1 mesochaetae;

Ch.19, median (M) 4th abdominal dorsal macrochaetae, 1. 1/ 2. 2/ 3. 3/ 4. 4/ 5. 0;

Ch.20, supplementary seta <4th abdominal segment>, 1. absent/ 2. present;

Ch.21, tenent hair shape, 1 . acuminate/2. clavate/ 3. truncate;

Ch.22, number of teeth of inner unguis, 1. 2/ 2. 3/ 3. 4/ 4. 0;

Ch.23, ungual wing tooth, 1. absent/ 2. present;

Ch.24, unguiculus wing tooth, 1. absent/2. minute/3. weak/ 4. fully developed;

Ch.25, unguiculus shape, 1. acuminate/ 2. clavate/ 3. basally swollen;

Ch.26, eyes per side, number;

Ch.27, inner setae manubrial plaque, 1. 1/2. 2/3. 3/ 4. 4/ 5. more than 4;

Ch.28, outer setae manubrial plaque, number;

Ch.29, habitat, 1. cave/2. surface/ 3. both cave and surface/ 4. under stones at low tide, in the sea;

Ch.30, region located, 1. Europe and North Africa/ 2. North America/ 3. Mexico, Central America, West Indies/ 4. South America/ 5. Sub-Saharan Africa/ 6. Asia/ 7. Australia/ 8. Oceania/ 9. New Zealand;

Ch.31, apical antennal bulb, 1. absent/2. present/ 3. Unclear;

Ch.32, apical organ of third ant. segment, 1. peg or rod-like/ 2. expanded (leaf shaped)/ 3. paddle-shaped;

Ch.33, maximum length, mm;

Ch.34, distance distal unpaired ungual tooth from base/total unguis, $\langle \%\rangle$;

Ch.35, antennal/cephalic diagonal, ratio;

Ch.36, differentiated inner seta on hind tibiotarsus, 1. unclear or absent/ 2. clear, acuminate/ 3. clear, truncate or clavate;

Ch.37, cephalic seta R0, 1. absent/ 2. present;

Ch.38, cephalic seta R1, 1. absent/ 2. present;

Ch.39, cephalic seta R2, 1. absent/ 2. present;

Ch.40, cephalic seta R3, 1. absent/ 2. present;

Ch.41, cephalic seta P, 1. absent/ 2. present;

Ch.42, anterior to pseudopore thoracic segment II seta, 1. absent/ 2. present;

Ch.43, unguiculus external edge, 1. smooth/2. serrate;

Ch.44, apical tooth of mucro, 1. similar than second/2. longer than second.

The symbol "-" means absence of data.

(1): following original description. (2): Mari Mutt 1986. (3): Christiansen 1998. (4): P. gajui syn. nov. has the same characters of $P$. bachae except for the Ch. 21 , that is "1".

Differences in bold.

The use of the presence/absence of the $\mathbf{S}$ and $\mathbf{T}$ setae on the head, the formula for the labial, second and third thoracic segments, second and fourth abdominal segments, and the presence of the accessory seta $\mathbf{s}$ of the anterior trichobothrial complex of fourth abdominal segment allows to separate the new species of the considered group. These characters have been selected among others because are easily observed in the specimens. The table 2 , with the 44 characters frequently used for the description of species of this genus, is sufficient to identify and compare the species of this group. These characters have been obtained studying the original papers of the species descriptions (Bagnall, 1939; Christiansen, 1960; Christiansen \& Bellinger, 1980, 1996, 1998; Gama, 1988; Gama \& Busmachiu, 2002; Gisin, 1967; Gisin \& Gama, 1972; Luciáñez \& Simón, 1994; Rusek, 1979; Wang et al., 2002; Wang et al., 2004) and completed using the program of Christiansen (2007).

P. bachae and P. gajui can be differentiated only by the shape of the tenent hair of the tibiotarsus (Luciáñez \& Simón, 1994). In our opinion this two species are the same because, in addition, $P$. gajui has been described using only one specimen from the same locality and date of $P$. bachae. For this reason we consider P. gajui a new synonym of $P$. bachae.

There are some problems with the characters in Table 2 for $P$. biunguiculata. In the original description, Ellis drew the $\mathbf{p}$ seta of abdominal tergite II, and presented a macrochaetae formula with two $\mathbf{M}$ macrochaetae 
on abdominal tergite IV but without $\mathbf{P}$ macrochaeta. Mari-Mutt (1986) compared the types with specimens from Puerto Rico and could not tell the specimens apart in that respect: the $\mathbf{p}(=\mathrm{a} 2 \mathrm{p})$ seta is absent, the $\mathbf{P}$ macrochaeta is present, and there is only one $\mathbf{M}$ macrochaeta. A few specimens from Puerto Rico were different by having $\mathbf{R}_{2}$ on the head. These characters have been updated in Table 2 .

The characters are only unknown for $P$. halophila, but its peculiar habitat (under stones uncovered at low tide, England) allows to suppose that is a valid and different species. In addition only P. ashmoleorum, P. caoi, P. espana and P. certa share with P. halophila by the presence of only two teeth in the inner unguis (Bagnall, 1939).

The reference for Spain of P. petterseni is erroneous because Bonet (1931) identified the two specimens used for the actual description of P. pseudopetterseni sp. nov. as P. petterseni. Posterior authors used this reference without test the specimens, found by us during the study of the Pseudosinella species in different collections from Spain Museums and particular collections for the preparation of the Entomobryomorpha volume of the "Fauna Iberica Project".

\section{Pseudosinella tietarensis sp. nov.}

Figs 7-12, Table 3

Type material. Santa María del Tietar, Ávila (Spain). Holotype: male, slide MNCN115coll2003(4)79, captured on surface, labeled as: "Zool. Suelo Santa María del Tietar La Canaleja (9-2) 7.vi.1982 Castañar quemado 1978 suelo -5 a -10 cms R01048 Pseudosinella fallax". Paratypes: 1 female in the same slide as holotype; slide MNCN115coll2003(4)82 (1 specimen), with the same information as holotype; slides MNCN115coll2003(4)80 (3 specimens) and 81 (3 specimens), labeled as: "Zool. Suelo Santa María del Tietar La Canaleja (9-1) 7.vi.1982 Castañar quemado 1978 resto gramineas y suelo -2 a $-5 \mathrm{cms}$ R01047 Pseudosinella". Biotope: grass and soil in a chestnut burning grove. Deposited in the Museo Nacional de Ciencias Naturales-CSIC (MNCN), Madrid (Spain).

Other material. Slide MNCN115col12003(4)86 (1 specimen), labeled as: "Zool. Suelo Piedralaves Adrado? 7.vi.1982 6 requemado 1978 y 1980 0-2 $\mathrm{cms}$ R01037 1 Pseudosinella"; slide MNCN115coll2003(4)87 (1 specimen), "Zool. Suelo Piedralaves Adrado? 7.vi.1982 (6-1) 2-4 cms quemado 1978 y 1980 R01038 1 Pseudosinella"; slide MNCN115coll2003(4)88 (3 specimens), "Zool. Suelo Piedralaves Las Rasillas 7.vi.1982 (8-1) No quemado P. pinea sotobosque aclarado 1,5-4,5 cms R01043 3 Pseudosinella". Biotope: the word "quemado" or "requemado" means burning.

Description. Maximum length 0,7-1.0 mm (Holotype: 0,68 mm). Apparently without pigment. $3+3$ eyes. Ratio antenna/cephalic diagonal 1,3 and 1,4. Antennal segments I/II/III/IV ratios 1/1,42/1,29/2,38. Sensorial setae $\mathbf{s}$ of the sensory organ of antennal segment III short and expanded (leaf shaped), with two sensilla on antennal segment II (Fig. 12). Apical region of the antennal segments II and III, with a pseudopore in an internal-ventral position, far from the setae line. Apical vesicle absent from antennal segment IV.

Formula of the labial base (Fig. 9): $\mathbf{M}_{1} \mathbf{M}_{2} \mathbf{r} \mathbf{E L}_{1} \mathbf{L}_{2}$ (all setae conspicuously ciliated except $\mathbf{r}$, that is a vestigial microchaeta).

Formula of the dorsal macrochaetae: R011/10/0101+2. Anterior seta to thoracic II pseudopore absent. Abdominal tergite II chaetotaxy: $-\mathbf{-} \mathbf{-} B \mathbf{q}_{1} \mathbf{q}_{\mathbf{2}}$ (Fig. 7), a as a ciliated microchaeta. In the $\mathbf{R}$ complex $\mathbf{R}_{\mathbf{0}}$ to $\mathbf{R}_{\mathbf{2}}$ are present (Fig. 8). Accessory seta $\mathbf{s}$ in the anterior trichobothrial complex of abdominal tergite IV is present (Fig. 10). Seta $\mathbf{P}$ on abdominal tergite IV located slightly anterior to the trichobothrium, half of the length of $\mathbf{M}_{1}$ and as ciliated mesochaeta (Fig. 10). Medial seta $\mathbf{M}_{1}$ located at the level of the trichobothrium $\mathbf{T}_{2}$ and pseudopore almost at the same level than $\mathbf{M}_{1}$.

Unguis (Fig. 11) with dental plate occupying 50\% of the basal internal edge; basal teeth of similar size, medial tooth well developed, approximately $65-70 \%$ from base of total unguis. Unguiculus appendage acumi- 
nate, always with a first developed external tooth and a second tooth or, sometimes, a more or less slightly developed serrated lamina. Tibiotarsi with clavate tenent hair. Legs without scales. Retinaculum with $4+4$ teeth and one ciliated seta. Two internal and two to three external setae related to two distal pseudopores of manubrial plate. Mucro with distal tooth equal than the anteapical; the basal spine reaches just to the tip of the first tooth.

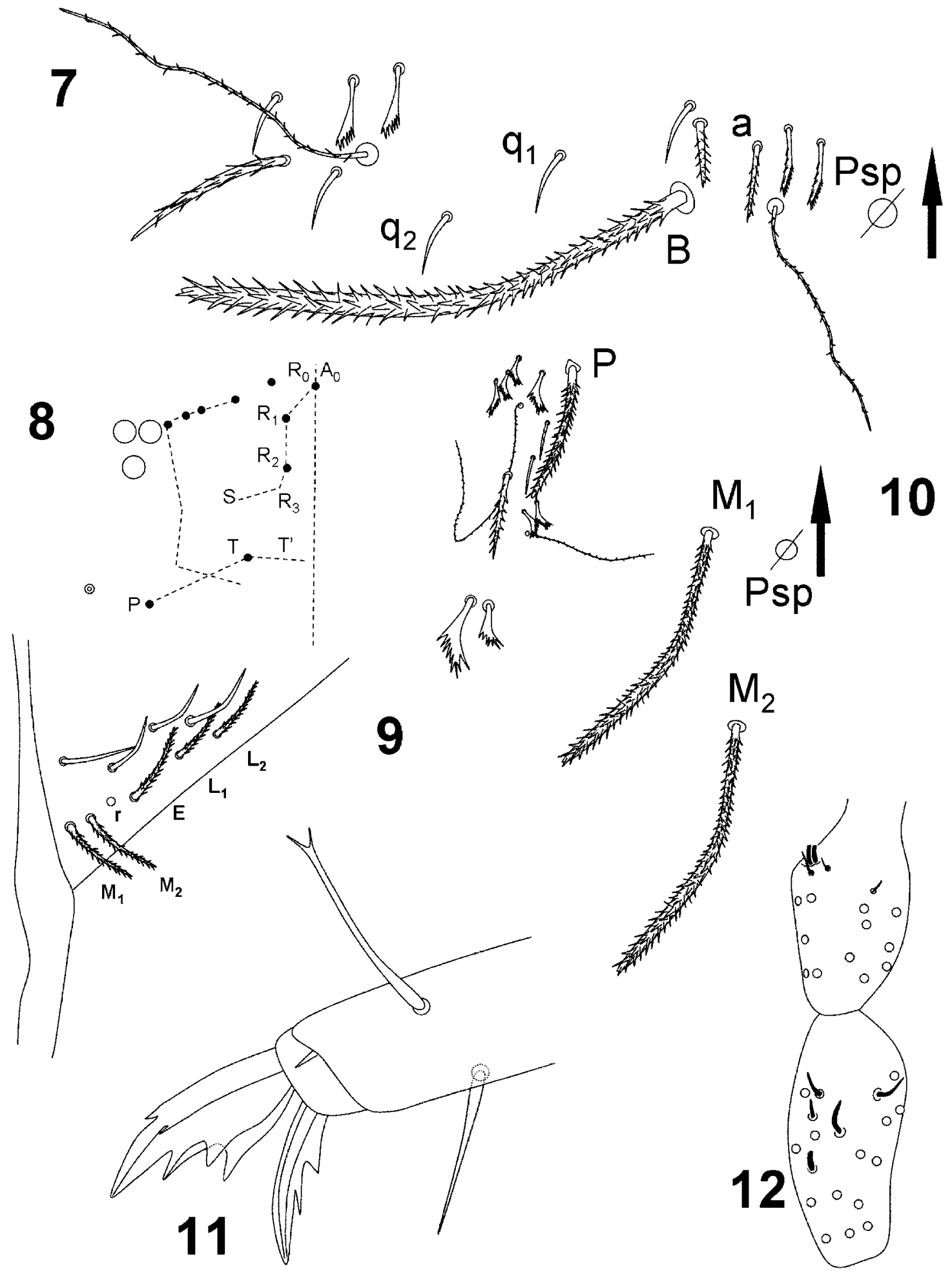

FIGURES 7-12. Pseudosinella tietarensis sp. nov.: 7, chaetotaxy of abdominal segment II; 8, head macrochaetotaxy; 9 , labium chaetotaxy; 10, trichobothrial complex of abdominal segment IV; 11, distal part of leg III; 12, second and third antennal segments. 
Etymology. The species name is referred to the locality: Valle del Tietar.

Discussion. $P$. tietarensis sp. nov. has the same chaetotaxy formula that $P$. cordobensis Simón et al., 1987 and $P$. arretzi Simón, 1981, that have the unguiculus smooth and with a big single teeth respectively; the new species has two teeth. In addition $P$. cordobensis has seta a from second abdominal segment smooth, four internal teeth on the unguis (the first single tooth at $74 \%$ from the basis), and without ungual wing tooth (Simón et al., 1987). P. arretzi has different unguiculus shape (Table 3).

\section{Pseudosinella jacetanica sp. nov.}

Figs. 13-19, Table 3

Type material. Monte Boalar, Jaca, Huesca (Spain). Holotype: female, slide MNCN115coll2003(4)62, captured on surface, labelled as: "Lab. ${ }^{\circ}$ Faunística [f\#?] agost 5\% panta Jaca Monte Boalar 2.v.1965 (9) Pseudosinella decipiens Denis [4]". Paratypes: slide MNCN115coll2003(4)63 (2 specimens), slide MNCN115coll2003(4)65 (2 specimens), slide MNCN115coll2003(4)70 (1 male). Deposited in the Museo Nacional de Ciencias Naturales-CSIC (MNCN), Madrid (Spain).

Other material. Slide MNCN115coll2003(4)64 (1 specimen), labeled as: "Zool. Suelo Jaca, Monte Boalar 13.xi.1965 (R021) 1 jacensis?"; slide MNCN115coll2003(4)73 (1 specimen), "Lab. ${ }^{\circ}$ Faunistica 5\% agost espatula? Arras Bailo Huesca Raíces espárragos 15-IX-66 leg. Puigdefabregas: MrEL Pseudosinella decipiens Denis R011/32/0201+2 no jacensis". Biotope: asparagus roots.

Description. Maximum length 1,25 mm (holotype: 0,78 mm). Apparently without pigment. Without eyes. Ratio antenna/cephalic diagonal 1,4 and 1,7. Antennal segments I/II/III/IV ratios 2,79/1,79/1,79/1. Sensorial setae $\mathbf{s}$ of the sensory organ of antennal segment III short and expanded (leaf shaped), and one more similar on antennal segment II. Apical vesicle absent from antennal segment IV.

Formula of the labial base (Fig. 15): $\mathbf{M}_{1} \mathbf{M}_{2} \mathbf{r E L} \mathbf{L}_{1} \mathbf{L}_{2}$ (all setae ciliated but very slightly, except $\mathbf{r}$, that is vestigial microchaeta). Formula of the dorsal macrochaetae: R011/32/0201+2 (Fig. 14). Anterior seta to pseudopore thoracic II absent. Abdominal tergite II chaetotaxy: $\mathbf{p} \mathbf{A} \mathbf{B} \mathbf{q}_{1} \mathbf{q}_{2}$ (Fig. 13). A of the length of $\mathbf{B}$. $\mathbf{R}$ complex of the head with $\mathbf{R}_{\mathbf{0}}$ to $\mathbf{R}_{\mathbf{2}}$ Accessory seta $\mathbf{s}$ in the anterior trichobothrial complex of abdominal tergite IV present (Fig. 16). Seta $\mathbf{P}$ on abdominal tergite IV anterior to the trichobothrium (Fig. 17). Medial seta $\mathbf{M}_{1}$ slightly above trichobothrium $\mathbf{T}_{2}$, pseudopore at the level of $\mathbf{M}_{2}$.

Unguis (Fig. 18) with dental plate occupying $50 \%$ of the basal internal edge; one of the basal tooth slightly bigger than the other one; medial tooth well developed, approximately $60 \%$ from base of total unguis. Ungual wing tooth present, but very difficult to see in some specimens. Unguiculus appendage acuminate, finely serrated. Tibiotarsi with acuminate tenent hair. Legs without scales. Retinaculum with $4+4$ teeth and one ciliated seta. Two internal and two to three external setae related to two distal pseudopores of manubrial plate. Mucro with distal tooth longer than the anteapical; the basal spine reaches just to the tip of the distal tooth (Fig. 19).

Etymology. The species name is referred to the locality: Jaca.

Discussion. Only P. subilliciens Mateos, 1993 and P. gineti Cassagnau, 1955 has the same macrochaetae formula that $P$. jacetanica sp. nov. $P$. gineti is a cavernicolous species with a very long unguis and with the following differences with the new species: labial base formula (all setae except $\mathbf{r}$ as smooth macrochaetae), sensorial seta $\mathbf{s}$ of the sensory organ of antennal segment III peg or rod-like, ratio antenna/cephalic diagonal 2,3, ungual wing tooth absent, unguiculus swollen and without teeth, and maximum length $3 \mathrm{~mm}$. P. subilliciens with macrochaetae of labial base (except for $\mathbf{r}$ ) clearly ciliated; tenent hair clavate and with three-four internal teeth on the unguis (Table 3). 


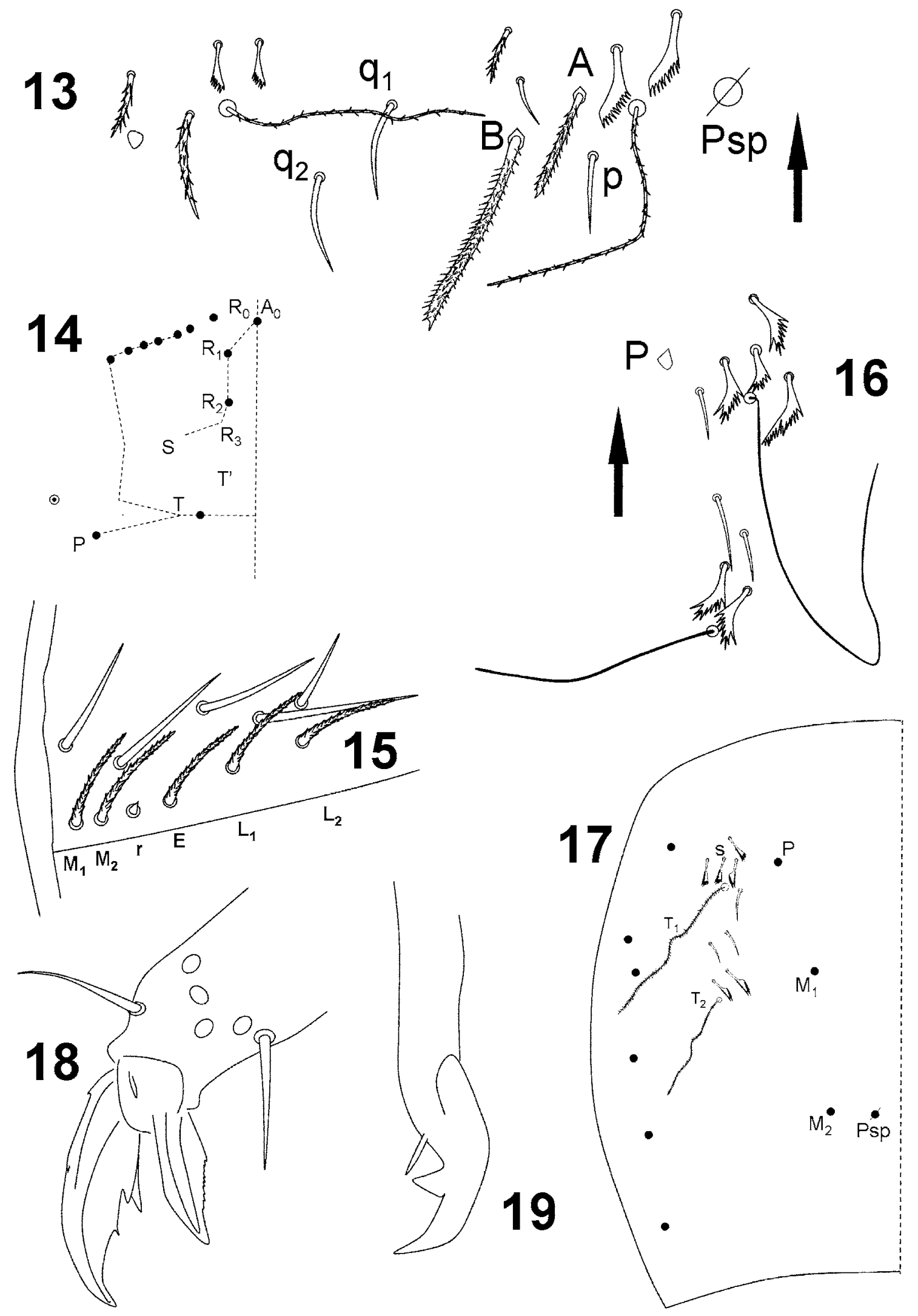

FIGURES 13-19. Pseudosinella jacetanica sp. nov.: 13, chaetotaxy of abdominal segment II; 14, head macrochaetotaxy; 15, labium chaetotaxy; 16, trichobothrial complex of abdominal segment IV; 17, macrochaetotaxy of abdominal segment IV; 18, distal part of leg III; 19, mucro. 
TABLE 3. Comparison of $P$. tietarensis sp. nov., $P$. jacetanica $\mathrm{sp}$. nov. and $P$. simoni $\mathrm{sp}$. nov. with the species sharing dorsal macrochaetotaxy, respectively. Character description in the legend of Table 2.

\begin{tabular}{|c|c|c|c|c|c|c|c|c|c|}
\hline Character & Range & $\begin{array}{l}\text { P. tietarensis } \\
\text { n. sp. }\end{array}$ & P. cordobensis & P. arretzi & $\begin{array}{l}\text { P. jacetanica } \\
\text { n. sp. }\end{array}$ & P. subilliciens & $P$. gineti & $\begin{array}{l}\text { P. simoni } \\
\text { n. sp. }\end{array}$ & P. sexoculata \\
\hline Ch.1 & $1-2$ & 1 & 1 & 1 & 1 & 1 & 1 & 1 & 1 \\
\hline Ch.2 & $1-2$ & 2 & 2 & 2 & 2 & 2 & 2 & 2 & 2 \\
\hline Ch. 3 & $1-7$ & 4 & 4 & 4 & 4 & 4 & 3 & 4 & 4 \\
\hline Ch.4 & $1-7$ & 4 & 4 & 4 & 4 & 4 & 3 & 4 & 3 \\
\hline Ch.5 & $1-5$ & 1 & 1 & 1 & 1 & 1 & 1 & 1 & 1 \\
\hline Ch.6 & $1-5$ & 4 & 4 & 4 & 4 & 4 & 3 & 4 & 3 \\
\hline Ch.7 & $1-5$ & 4 & 4 & 4 & 4 & 4 & 3 & 4 & 3 \\
\hline Ch. 8 & $1-5$ & 4 & 4 & 4 & 4 & 4 & 3 & 4 & 3 \\
\hline Ch.9 & $1-5$ & 2 & 1 & $1-2$ & 4 & 4 & 4 & 2 & 1 \\
\hline Ch.10 & $1-5$ & 4 & 4 & 4 & 4 & 4 & 4 & 4 & 4 \\
\hline Ch.11 & $1-5$ & 1 & 1 & 1 & 2 & 2 & 2 & 1 & 2 \\
\hline Ch.12 & $1-5$ & 1 & 1 & 1 & 1 & 1 & 1 & 4 & 4 \\
\hline Ch.13 & $1-5$ & 1 & 1 & 1 & 1 & 1 & 1 & 1 & 1 \\
\hline Ch.14 & $1-4$ & - & - & - & - & - & - & 4 & 4 \\
\hline Ch.15 & $0-\mathrm{n}$ & 1 & 1 & 1 & 3 & 3 & 3 & 0 & 0 \\
\hline Ch.16 & $1-3$ & 3 & 3 & 3 & - & - & - & 3 & 3 \\
\hline Ch.17 & $0-2$ & 0 & 0 & 0 & 2 & 2 & 2 & 0 & 0 \\
\hline Ch.18 & $1-2$ & 2 & 2 & 2 & 2 & 2 & 2 & 2 & 2 \\
\hline Ch.19 & $1-5$ & 2 & 2 & 2 & 2 & 2 & 2 & 2 & 2 \\
\hline Ch.20 & $1-2$ & 2 & 2 & 2 & 2 & 2 & 2 & 2 & 2 \\
\hline Ch.21 & $1-3$ & 2 & 2 & 2 & 1 & 2 & 1 & 2 & 2 \\
\hline Ch.22 & $1-4$ & 2 & 3 & 3 & 2 & $2-3$ & 1 & 2 & 2 \\
\hline Ch.23 & $1-2$ & 2 & 1 & 1 & 2 & 1 & 1 & 2 & 1 \\
\hline Ch.24 & $1-4$ & 3 & 1 & 4 & 1 & 1 & 1 & 2 & 1 \\
\hline Ch.25 & $1-3$ & 1 & 1 & 3 & 1 & 1 & 3 & 1 & 3 \\
\hline Ch.26 & $\mathrm{n}$ & 3 & 3 & 3 & 0 & 0 & 0 & 3 & 3 \\
\hline Ch.27 & $1-5$ & 1 & - & 2 & 2 & 2 & - & 2 & 2 \\
\hline Ch.28 & $0-\mathrm{n}$ & $2-3$ & - & 2 & 3 & 2 & - & 2 & $2-3$ \\
\hline Ch.29 & $1-3$ & 2 & 2 & 2 & 2 & 2 & 1 & 2 & 3 \\
\hline Ch.30 & $1-9$ & 1 & 1 & 1 & 1 & 1 & 1 & 1 & 1 \\
\hline Ch.31 & $1-3$ & 1 & - & 1 & 1 & 1 & - & 1 & 1 \\
\hline Ch.32 & $1-3$ & 1 & 1 & 1 & 2 & - & 1 & 2 & 1 \\
\hline Ch.33 & $\mathrm{n}$ & 1 & 0,84 & 0,9 & 1,25 & 1,2 & 3 & 1.3 & 1,4 \\
\hline Ch.34 & $\%$ & $65-70 \%$ & 0.9 & 0.7 & 0.6 & 0.66 & 0.4 & 0.7 & 0.75 \\
\hline Ch.35 & $\mathrm{n}$ & $1,3-1,4$ & 1,5 & 1,4 & $1,4-1,7$ & $1,5-1,84$ & 2.3 & $1,3-1.5$ & $1,3-1,4$ \\
\hline Ch.36 & $1-3$ & - & - & - & & & & - & - \\
\hline Ch.37 & $1-2$ & 2 & 2 & 2 & 2 & 2 & 2 & 2 & 2 \\
\hline Ch.38 & $1-2$ & 2 & 2 & 2 & 2 & 2 & 2 & 2 & 2 \\
\hline Ch.39 & $1-2$ & 2 & 2 & 2 & 2 & 2 & 2 & 2 & 2 \\
\hline Ch.40 & $1-2$ & 1 & 1 & 1 & 1 & 1 & 1 & 1 & 1 \\
\hline Ch.41 & $1-2$ & 2 & 2 & 2 & 2 & 2 & - & 2 & 1 \\
\hline Ch.42 & $1-2$ & 1 & 1 & 1 & 1 & 1 & - & 1 & 1 \\
\hline Ch.43 & $1-2$ & 2 & 1 & 1 & 2 & 2 & 1 & 2 & 1 \\
\hline Ch.44 & $1-2$ & 2 & 2 & 1 & 2 & - & 2 & 2 & - \\
\hline
\end{tabular}




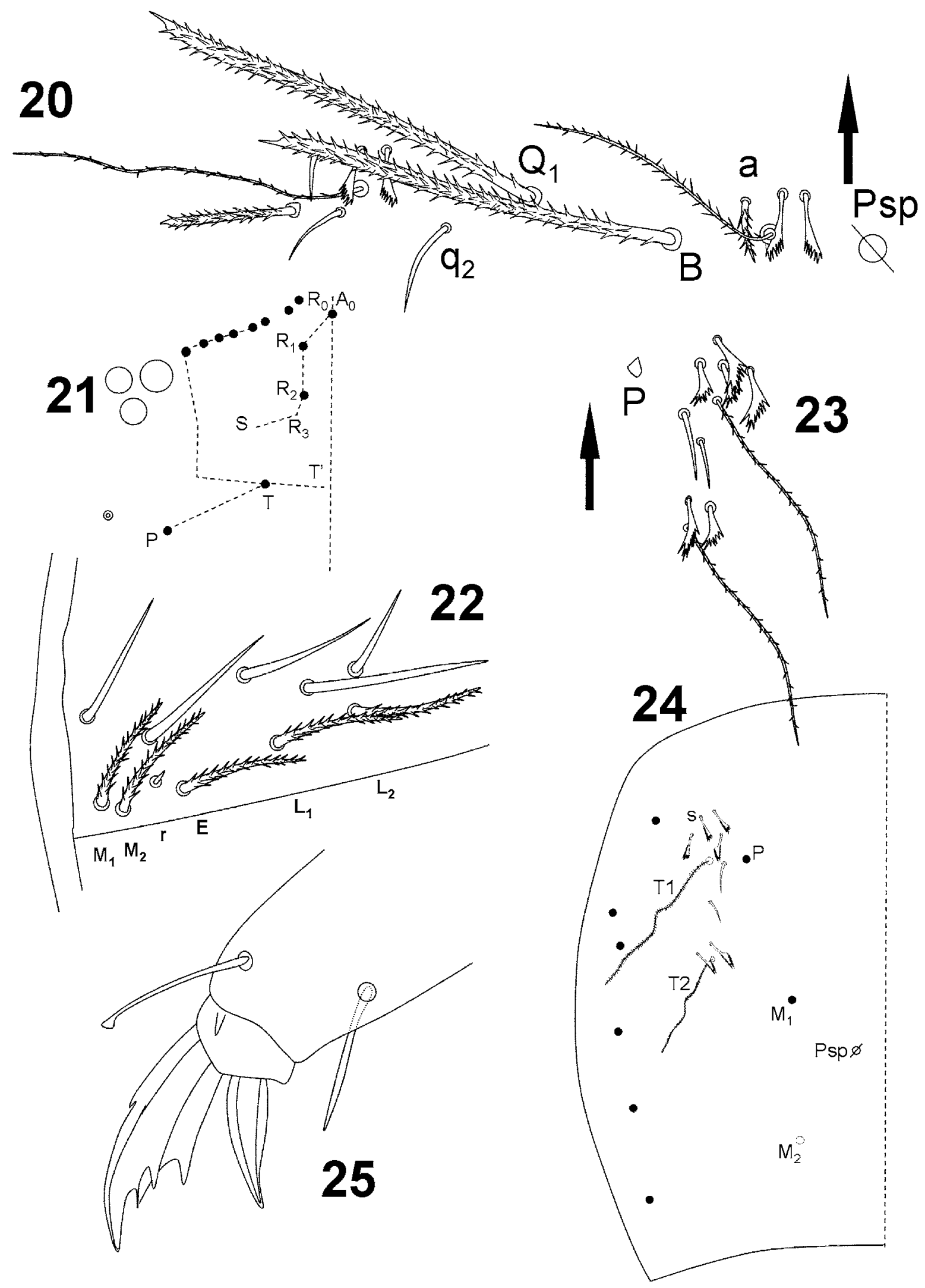

FIGURES 20-25. Pseudosinella simoni sp. nov.: 20, chaetotaxy of abdominal segment II; 21, head macrochaetotaxy; 22, labium chaetotaxy; 23, trichobothrial complex of abdominal segment IV; 24, macrochaetotaxy of abdominal segment IV; 25, distal part of leg III. 
Type material. Navacerrada, Madrid (Spain). Holotype: female, slide MNCN115coll2003(4)83, captured on surface, labeled as: "Lab. Faunística Ex. Navacerrada antes albergues, Hojarasca Sarothamnus purgans y Juniperus nana micelio de hongos X-1959, 4 ojos R011/00/0201+2 Pseudosinella fallax MMrELL 2/7B1". Biotope: fungus mycelium on litter. Paratypes: slide MNCN115coll2003(4)84 (1 specimen), labeled as: "Lab. Faunística 10-1959 Ex. Navacerrada derecha carretera antes albergues Ranker mulliforme Musgos Z/ 65, 3 ojos R01?/00/0201+2 Pseudosinella fallax Börner B Z/65". Biotope: moss; slide MNCN115coll2003(4)85 (3 specimens), labeled as: "Lab. Faunística 3 ojos Pseudosinella fallax Börner 2 ejempl /00/ /10/ Navacerrada Z-7D X-1959 D"; slide MNCN115coll2003(4)91 (9 specimens in a slide very damaged), labeled as: "Lab. Faunística Pueblo de Navacerrada 9.xi.1961 (16) Pseudosinella fallax Börner varios ejemplares"; slide MNCN115coll2003(4)92 (5 specimens), labeled as: "Lab. Faunística Pueblo Navacerrada 9.xi.1961 (16) Pseudosinella fallax 9-XI-61". Deposited in the Museo Nacional de Ciencias Naturales-CSIC (MNCN), Madrid (Spain).

Other material. Slide MNCN115coll2003(4)90 (3 specimens), labeled as: " Lab. Faunística Valsaín 26.v.1963 E (5) 3 ojos Pseudosinella fallax Börner".

Description. Maximum length 1,0-1.3 mm (Holotype: 1,05 mm). Apparently without pigment. 3+3 eyes. Ratio antenna/cephalic diagonal 1,3 and 1,5. Antennal segments I/II/III/IV ratios 2.05/1.14/1.31/1.00 $(\mathrm{n}=2)$. Sensorial seta $\mathbf{s}$ of the sensory organ of antennal segment III expanded (leaf shaped). Apical vesicle absent from antennal segment IV.

Formula of the labial base (Fig. 22): $\mathbf{M}_{1} \mathbf{M}_{2} \mathbf{r E L} \mathbf{L}_{1} \mathbf{L}_{2}$ (all setae ciliated except $\mathbf{r}$, that is a vestigial microchaeta.

Formula of the dorsal macrochaetae: R011/00/0201+2. Anterior seta to pseudopore thoracic II absent. Abdominal tergite II chaetotaxy: $-\mathbf{-} \mathbf{B} \mathbf{Q}_{1} \mathbf{q}_{2}$ (Fig. 20). B and $\mathbf{Q}$ as broad ciliated and pointed macrochaetae. $\mathbf{R}$ complex: $\mathbf{R}_{\mathbf{0}}$ to $\mathbf{R}_{\mathbf{2}}$ present (Fig. 21). Accessory seta $\mathbf{s}$ in the anterior trichobothrial complex of abdominal tergite IV present (Fig. 23). Seta $\mathbf{P}$ on abdominal tergite IV slightly anterior to the trichobothrium (Fig. 24). Medial seta $\mathbf{M}_{1}$ between the trichobothria $\mathbf{T}_{1}$ and $\mathbf{T}_{2}$; pseudopore nearest $\mathbf{M}_{1}$.

Unguis (Fig. 25) with dental plate occupying $60 \%$ of the basal internal edge; one of the basal tooth slightly bigger than the other one; medial tooth well developed, approximately $70 \%$ from base of total unguis. Unguiculus appendage acuminate with small denticles. Dorsal tibiotarsi tenent hair clavate. Legs without scales. Retinaculum with $4+4$ teeth and one ciliated seta. Two internal and two external setae related to two distal pseudopores of manubrial plate. Mucro with distal tooth longer than the anteapical; the basal spine reaches just to the tip of the distal tooth.

Etymology. The species name is dedicated to Dr. José Carlos Simón, Spanish collembologist.

Discussion. $P$. simoni sp. nov. has a unique macrochaetotaxy. The closest species with the same macrochaetae formula is: $P$. sexoculata Schött, $1902\left(3+3\right.$ eyes, $\mathbf{R 0 1 1 / 0 0 / 0 2 0 1 + 2 , ~} \mathbf{p a B Q} \mathbf{Q}_{\mathbf{1}} \mathbf{q}_{\mathbf{2}}, \mathbf{M}_{\mathbf{1}} \mathbf{m}_{\mathbf{2}} \mathbf{r} \mathbf{r l}_{\mathbf{1}} \mathbf{l}_{2}$, accessory seta $\mathbf{s}$ present) (Table 3).

\section{Acknowlegement}

We thanks to Dr. Carolina Martín (MNCN) for the loan of the type specimens, found among the slides of the Collembola collection of the Museo Nacional de Ciencias Naturales-CSIC. 


\section{References}

Bagnall, R. S. (1939) Notes on British Collembola. V. Entomologist's Monthly Magazine, 75, 188-200.

Bonet, F. (1931) Estudios sobre Colémbolos cavernícolas con especial referencia a los de la fauna española. Memorias de la Real Sociedad de Historia Natural, 14, 231-403.

Börner, C. (1901) Neue Collembolenformen und zur Nomenclatur der Collembola Lubbock. Zoologische Anzeiger, 24, 696-712.

Cassagnau, P. (1955) Faune francaise des collemboles. VI. Collemboles cavernicoles du Vercors. Notes biospéleologiques, 10, 35-40.

Chen, J.-X., Wang, F. \& Christiansen K. A. (2002) A new species of Pseudosinella from Guilin, China (Collembola: Entomobryidae). Journal of the Kansas Entomological Society, 75(2), 80-85.

Christiansen, K. (1960) The Genus Pseudosinella (Collembola, Entomobryidae) in Caves of the United States. Psyche, $67(1-2), 1-25$.

Christiansen, K. (1982) Notes on mexican cave Pseudosinella (Collembola: Entomobryidae) with the description of six new species. Folia Entomológica Mexicana, 53, 3-25.

Christiansen, K. (2007) Pseudosinella Database Page. http://www.math.grinnell.edu/ twitchew/coll/

Christiansen, K., Bellinger, P. (1980) The Collembola of North America, north of the Rio Grande. A taxonomic analysis. Part 3. Family Entomobryidae. Grinnell College. Grinnell, IA. 785-1042.

Christiansen, K., Bellinger, P. (1996) Cave Pseudosinella and Oncopodura, New to Science, Journal of Caves and Karst Studies, 58(1), 38-53.

Christiansen, K., Bellinger, P. (1998) The Collembola of North America, North of the Rio Grande. A taxonomic analysis. Part 3. Families Entomobryidae, Cyphoderidae, Paronellidae, Oncopoduridae, Tomoceridae. Grinnell College. Grinnell, IA. 887-1174.

Christiansen, K., Bellinger, P. \& Gama, M.M. da (1990) Computer Assisted Identification of Specimens of Pseudosinella (Collembola Entomobryidae). Revue d'Écologie et de Biologie du Sol, 27(2), 231-246.

Christiansen, K., Gama, M.M. da \& Bellinger, P. (1983) A catalogue of the species of the genus Pseudosinella. Ciencia Biologica. Ecology and Systematics, 5, 13-31.

Ellis, W. N. (1967) Studies on Neotropical Collembola, I. Some Collembola from Guatemala. Beufortia, 14(171), 93107.

Folsom, J. W. (1924) New species of Collembola from New York State. American Museum novitates, 108, 1-12.

Gama, M. M. da (1988) Systématique évolutive des Pseudosinella. XIV. Deux espèces nouvelles provenant des Açores (Insecta: Collembola). Revue suisse de Zoologie, 95(2), 607-611.

Gama, M. M. da \& Busmachiu, G. (2002) Systématique évolutive es Pseudosinella. XVI. Espèces édaphiques de la Moldavie (Insecta: Collembola). Revue suisse de Zoologie, 109(4), 679-685.

Gisin, H. (1967) Espèces nouvelles et lignées évolutives de Pseudosinella endogés (Collembola). Memórias e Estudos do Museu Zoológico da Universidade de Coimbra, 301, 6-25.

Gisin, H., \& Gama, M. M. da (1972) Pseudosinella cavernicoles d'Espagne (Insecta: Collembola). Revue Suisse de Zoologie, 79, 261-278.

Luciáñez, M. J. \& Simon, J. C. (1994) Cinco especies nuevas del género Pseudosinella (Collembola: Entomobryidae) de la Península Ibérica. Annales de la Société Entomologique de France (Nouvelle série), 30(3), 319- 27.

Mateos, E. (1993). Pseudosinella subilliciens sp. nov., una nueva especie de Pseudosinella (Collembola, Entomobryidae) edáfica del noroeste ibérico (Catalunya, España). Graellsia, 49, 87-90.

Mari Mutt, J. (1986) Puerto Rican species of Lepidocyrtus and Pseudosinella (Collembola: Entomobryidae). Caribean Journal of Science, 22(1-2), 1-48.

Mills, H. B. (1932) New and rare north American Collembola. Iowa State College Journal of Science, 6, $263-273$.

Rusek, J. (1979) Two new species of Collembola from cultivated soils of Czechoslovakia. Vestník Československé Společnosti Zoologické, 43(2), 143-147.

Schött, E. (1902) Etudes sur les collemboles du nord. Bihang till Kungliga Svenska Vetenskaps-Akademiens Handlingar, 28(4), 1-48

Simón, J. C. (1981) Pseudosinella arretzi nov. sp. de la sierra de Gredos. Eos, 55-56, 215-218.

Simón, J. C., Bach, C. \& Gaju, M. (1987) Colembolos de la provincia de Cordoba (España) (Nota 1). Eos, 62, $297-306$.

Simón, J. C. \& Signoret, A. (2006) Nueva especie de Pseudosinella Schaeffer, 1897 de la península Ibérica (Collembola, Entomobryidae). Graellsia, 62(2), 199-202.

Wang, F., Chen, J.-X. \& Christiansen, K. (2004) A survey of the Genus Pseudosinella (Collembola: Entomobryidae) from East Asia. Annals of the Entomological Society of America, 97(3), 364-385.

Wang, F., Christiansen, K. \& Chen, J.-X. (2002) A new species of Pseudosinella from China (Collembola: Entomobryidae). Entomological News, 113(1), 63-67. 